\title{
Lagochilascaris minor: Specific antibodies are related with resistance to experimental infection in $\mathbf{A} / \mathbf{J}$ strain of mice
}

\author{
M. F. S. PRUDENTE, J. G. FREITAS, E. L. RIBEIRO, M. S. CARVALHAES
}

\begin{abstract}
Department of Microbiology, Immunology, Parasitology and Pathology, Institute of Tropical Pathology and Public
\end{abstract} Health, Federal University of Goiás, Goiânia - Brazil, E-mail: msilvia@iptsp.ufg.br; maracarvalhaes@bol.com.br

\begin{abstract}
Summary
Lagochilascaris minor is the causative agent of human lagochilascariosis, a disease that affects the neck region causing abscesses with eggs, adult parasites and L3/L4 larvae within purulent exudates. Nowadays, mice are considered intermediary hosts for the parasite. In previous study we observed that $\mathrm{A} / \mathrm{J}$ mice experimentally infected with Lagochilascaris minor showed higher survival ratios than B10.A mice. Now, we denoted that A/J mice (resistant to experimental infection) produced higher levels of $\operatorname{IgM}, \operatorname{IgG}$ and $\operatorname{IgA}$ against the crude extract (excepted for IgM) and secreted/excreted antigens of the parasite; on the other hand, B10.A mice (susceptible to experimental infection) produced higher levels of $\mathrm{IgE}$ in the later period of the experimental infection than $\mathrm{A} / \mathrm{J}$ infected mice.
\end{abstract}

Keywords: B cells; Lagochilascaris minor; helminth; Immunoglobulin, serology

\section{Introduction}

Five species of Lagochilascaris have been described: $L$. major and L. buckleyi in felines, L. turgida and L. sprenti in marsupials, and L. minor in dogs, cats and human cases (Leiper, 1909). L. minor is considered an abnormal parasite of humans and it is an emerging helmintosis limited to the Neotropical area (Mexico to Brazil), but infected cats have been found in Uruguay (Sakamoto \& Cabrera, 2002). The lagochilascariosis is not yet a public health problem, but it is prevalent in individuals of the lowest social-economic class, notably from rural areas. The majority of reported cases of infection have been in persons of both sexes, with lesions usually chronic, affecting the neck and head tissues with abscess formation. Sometimes the parasite invades the pulmonary tissue and central nervous system in fatal cases. Frequently, L. minor lesions contain different stages (eggs, larvae and adult worm) of the parasite which indicates autoinfection and favors the development of chronic di- sease (Fraiha et al., 1989; Volcan et al., 1992).

The extraordinary capacity of L. minor to migrate across different human tissues can be also observed in animal models of the disease such as in mice and cats. In mice orally inoculated with infective parasite eggs, hatched larvae can be observed in the intestinal tract, with third stage larvae (L3) migrating through intestinal mucosa reaching vessels and hepatic parenchyma and disseminating to other tissues such as lungs, skeletal muscles and subcutaneous tissues. In cats that eat infected mice, L3 larvae migrate through the esophagus, pharynx, trachea and cervical lymph nodes (Semerene et al., 2004).

Infected B10.A mice (susceptible strain) had a lower survival ratio $(24 \%)$ than $\mathrm{A} / \mathrm{J}$ mice $(90 \%$, resistant strain) and more intense lesions in the lungs (Prudente et al., 2009a; Spadafora-Ferreira et al., 2010); then, the major focus of this research was the study and the correlation of the humoral immune response during experimental lagochilascariosis with susceptibility and resistance in different strains of mice.

\section{Materials and methods}

Animals and parasites

Six to eight-week-old B10.A and A/J male mice were purchased from the University of Campinas Animal Facility, and kept with food and water ad libidum and handled according to the local regulations. The Research Ethics Committee of the Federal University of Goiás approved the research protocols.

Eggs from the parasite were collected from feces of Felis domesticus experimentally infected with a human isolate of L. minor. Feces from infected animals were submitted to Hoffman's method, kept in culture in formalin solution $(1 \%)$ at room temperature for 30 days, and after the development of the infective eggs containing third-stage larvae, cultures were submitted to Faust's method for the best 
recovery of eggs free of fecal debris (Oliveira et al., 2002). Egg suspensions were exhaustively washed with phosphate buffered saline and the eggs were counted on microscope slides. The final concentration was adjusted to $10^{4} \mathrm{eggs} / \mathrm{ml}$.

\section{Experimental infection design}

Forty B10.A and forty $\mathrm{A} / \mathrm{J}$ male mice were orally inoculated with a suspension of $10^{3} \pm 200 \mathrm{~L}$. minor eggs per animal and five mice were sacrificed at different time points (from 15 to 210 days post-infection) and subjected to necropsy for collection of blood for serum separations to determination of specific immunoglobulin. Twenty-four uninfected control B10.A and A/J mice received saline orally and were used as control for serological analysis (3 animals sacrificed at different days after the beginning of infection).

\section{Antibody detection}

For crude extract antigen preparation (CE), parasite larvae obtained from subcutaneous and skeletal nodules of infected mice were washed thoroughly in sterile $\mathrm{NaCl}$ $0.85 \%$, and disrupted in a TK8- IKA tissue breaker using Tris $0.1 \mathrm{M}, \mathrm{pH} 7.5$ containing a cocktail of protease inhibitors - all from Sigma (PMSF $1 \mathrm{mM}$; EDTA $1 \mathrm{mM}$; Leupeptin $5 \mu \mathrm{M}$, Aprotinin $2.5 \mu \mathrm{M}$ ). For secreted/ excreted antigen preparation (SE), parasite larvae were washed thoroughly in sterile $\mathrm{NaCl} 0.85 \%$, incubated overnight at $37{ }^{\circ} \mathrm{C}$ in Tris $0.1 \mathrm{M}, \mathrm{pH} \mathrm{7.5}$, and after collection of the fluid phase, a cocktail of protease inhibitors was added. Protein concentration was determined by the BCA (Pearce) method according to the manufacturer's instructions. To detect anti- L. minor antibodies, microtiter ELISA plates (Costar) were coated with antigen $(50 \mu \mathrm{g} / \mathrm{ml})$ and sera were used diluted 1/100 for IgG, M, A determination, and $1 / 50$ for $\operatorname{IgE}$ determination. Anti-mouse $\operatorname{IgG}, \operatorname{IgM}$ and $\operatorname{Ig} \mathrm{A}$ antibodies conjugated to peroxidase, anti-rat IgG conjugated to peroxidase and rat monoclonal-IgG antimouse IgE antibodies, were purchased from Sigma. Antibody binding was detected by utilizing orthophenylenediamine and hydrogen peroxide as chromogen and substrate, respectively. Optimal dilution of reagents was established in our laboratory. Plates were read at 492nm on a Multiskan EX Labsystems. Cut-off value was determined by taking the mean OD of 24 control subjects plus three standards deviation (Freitas et al., 2009; Prudente et al., 2009b).

\section{Statistical analysis}

Data were expressed as mean and standard deviations. Data of two groups were analysed by the Mann-Whitney $U$-test; and the data from multiple groups were analysed by an ANOVA test followed by a multiple comparison test (Dunn's test). (Program Prism 4.0).

\section{Results}

The kinetic of L. minor specific antibody level for each immunoglobulin $(\mathrm{Ig})$ isotype is shown in Figs. $1 \mathrm{~A}-1 \mathrm{H}$.
We found a marked difference in the pattern of the antibody response elicited in B10.A and $\mathrm{A} / \mathrm{J}$ infected mice for both antigens of $L$. minor, CE and SE: the level of antibodies of $\mathrm{A} / \mathrm{J}$ mice was always larger, except for IgM specific to the CE, and IgE.

IgM antibodies anti-CE antigens were detected at 60 to 90 and at 150 to 180 days post-infection in $\mathrm{A} / \mathrm{J}$ mice, and in B10.A mice at 15 to 30 and 150 to 210 days after infection (cut off $\mathrm{OD}=0.15 \mathrm{~nm}$ ), but in an inconsistent way (Fig. 1A). IgM antibodies anti-SE antigens were detected at 30 to 210 days post-infection in $\mathrm{A} / \mathrm{J}$ and B10.A infected mice (cut off $\mathrm{OD}=0.1 \mathrm{~nm}$ ), but $\mathrm{A} / \mathrm{J}$ mice presented higher levels of specific IgM when compared to B10.A infected mice, after the 120 days of infection (Fig. $1 \mathrm{~B}$ ).

IgA antibodies anti-CE antigens were detected at 30 to 210 days post-infection in $\mathrm{A} / \mathrm{J}$ and B10.A infected mice (cut off $\mathrm{OD}=0.1 \mathrm{~nm}$ ), but in the $\mathrm{A} / \mathrm{J}$ strain specific $\mathrm{IgA}$ against the $\mathrm{CE}$ were detected in higher levels after the 90 days of infection (Fig. 1C). IgA antibodies anti-SE antigens were detected at 30 to 210 days post-infection in $\mathrm{A} / \mathrm{J}$ infected mice and at 30 to 150 days post-infection in B10.A mice (cut off $\mathrm{OD}=0.1 \mathrm{~nm}) . \mathrm{A} / \mathrm{J}$ mice presented again higher levels of specific IgA against SE antigen when compared to B10.A infected mice after the 30 days of infection (Fig. 1D).

Specific IgG antibodies against the CE were detected at 15 to 210 days post-infection (cut off $\mathrm{OD}=0.1 \mathrm{~nm}$ ) in both strains (excepted 60 days post-infection in B10.A strain), but $\mathrm{A} / \mathrm{J}$ infected mice presented higher levels of $\mathrm{IgG}$ when compared to B10.A infected mice during the whole study period (Fig. 1E). Against the SE antigen (Fig. 1F), we observed an antibody production in both strains of mice (Cut off $\mathrm{OD}=0.15 \mathrm{~nm}$ ), but $\mathrm{A} / \mathrm{J}$ infected mice also presented higher levels of IgG when compared to B10.A infected mice after the 30 days of infection.

Specific IgE antibodies against the CE were detected at 30 and 60 days post-infection (cut off $\mathrm{OD}=0.023 \mathrm{~nm}$ ) in $\mathrm{A} / \mathrm{J}$ infected mice, and at 180 and 210 days post-infection in B10.A infected mice (Fig. 1G), but in small amounts. Against the SE antigen (Fig. 1H), we observed an antibody production at 30 and 120 days post-infection (cut off OD = $0.023 \mathrm{~nm}$ ) in $\mathrm{A} / \mathrm{J}$ infected mice, and at 120 to 210 days post-infection in B10.A infected mice (Cut off OD $=0.35$ $\mathrm{nm})$, also in low amounts. Although the $\operatorname{IgE}$ antibodies levels have been low, a tendency of production of greater quantities of this immunoglobulin was observed in $\mathrm{A} / \mathrm{J}$ mice at the initial phase of infection (30 to 120 days), and in B10.A animals at the final phase of infection (150 to 210 days).

The levels of antibodies against the SE antigen were larger for all classes of antibodies (IgM, IgG and $\operatorname{IgE}$ ), excepted for IgA, that reacted better with the $\mathrm{CE}$ of the parasite.

\section{Discussion}

The humoral immune response has been shown to provide an innate-like response involving B1 and spleen zone marginal cells, and an adaptative immune response involving conventional follicular B2-cells (Acosta Rodrigues et al., 

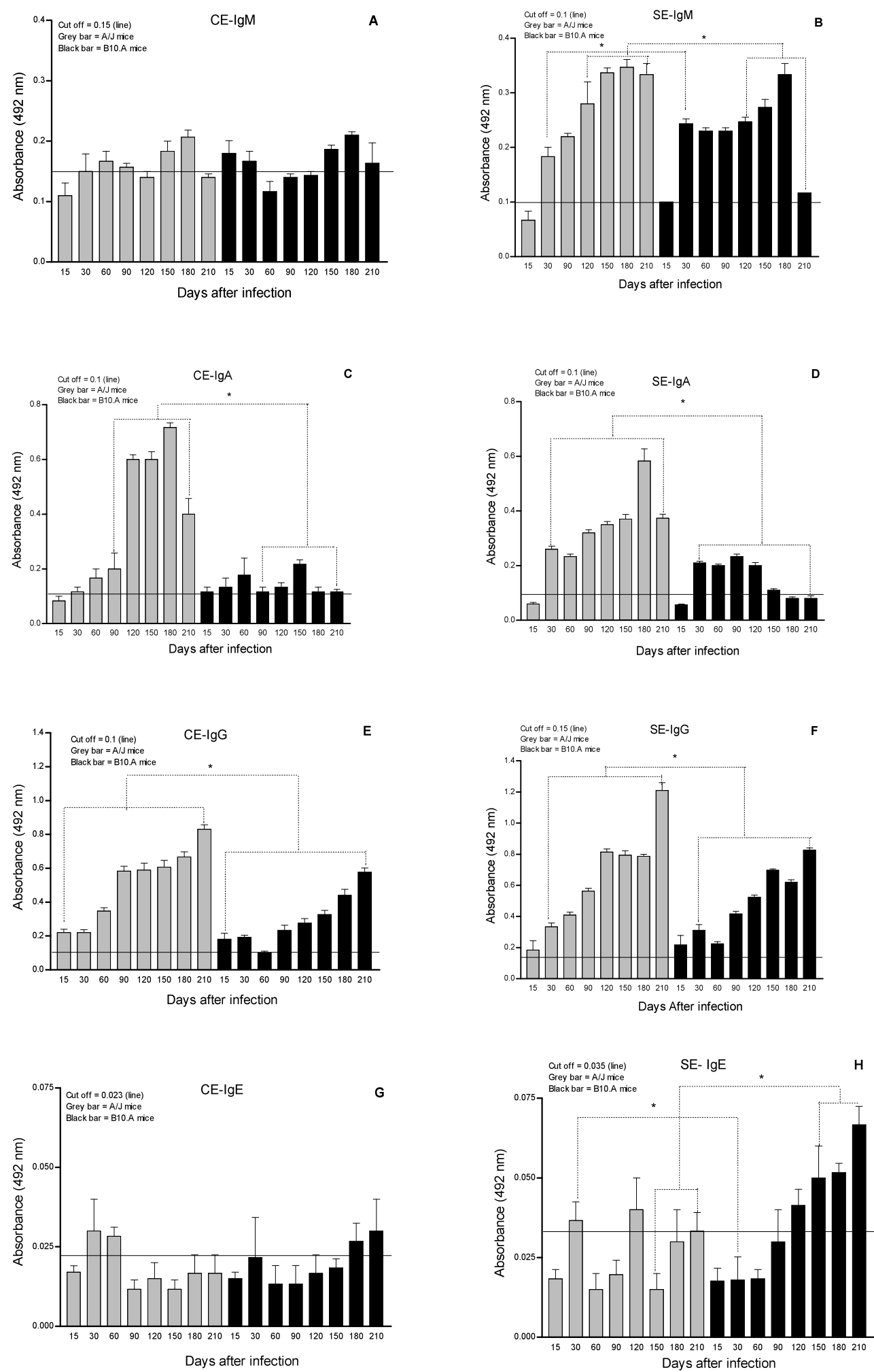

Fig. 1. Kinetics of immunoglobulin isotypes according to ELISA in A/J (grey bar) and B10.A (black bar) mice infected with Lagochilascaris minor, against the crude extract (CE) or the secreted/excreted antigen (SE) of the parasite. IgM isotype (A-B); IgA isotype (C-D); IgG isotype (E-F); IgE isotype (G-H). Results are expressed as average of five mice $\pm \mathrm{SD}\left({ }^{*} p \leq 0.05\right)$. 
2007; Prudente et al., 2009c). B1 cells usually interact with antigens that present repetitive epitopes (TI-2), producing great amounts of IgM, IgA and IgG3 (Kroese et al., 1995). In $\mathrm{A} / \mathrm{J}$ and B10.A mice with experimental lagochilascariosis, the levels of $\operatorname{IgM}, \operatorname{IgA}$ and $\operatorname{IgG}$ antibodies turn positive at the beginning of the infection (15-30 days), against the crude extract (CE) and mainly against the secreted/excreted antigens (SE), and these remained positive during the whole study period in A/J infected mice (210 days).

In the same way, we denoted in a previous work that $\mathrm{BALB} / \mathrm{c}$ infected mice produced $\operatorname{IgM}, \operatorname{IgA}, \mathrm{IgG}$, and also IgE against the crude extract and mainly against secreted/excreted antigens of the parasite (Freitas et al., 2009). On the other hand, we observed that C57BL/6 mice infected with $L$. minor produced $\operatorname{IgM}, \operatorname{IgG}$, and $\operatorname{IgA}$ mainly against the crude extract than against secreted/excreted antigens of the parasite (Prudente et al., 2009b).

Although the amount of IgE found is small, the levels of IgE were higher in $\mathrm{A} / \mathrm{J}$ (resistant) than in B10.A (susceptible) infected mice at 30 to 60 days post-infection against the $\mathrm{CE}$ of the parasite; however, the levels of $\operatorname{IgE}$ were higher in B10.A than in $\mathrm{A} / \mathrm{J}$ infected mice at 150 to 210 days post-infection against the SE antigens of the parasite. These results can't confirm the participation of specific$\mathrm{IgE}$ in the resistance to experimental lagochilascariosis, as it is observed in a big number of helmintosis

The levels of $\operatorname{IgA}$ and $\operatorname{IgG}$ against the CE, and of $\operatorname{IgM}, \operatorname{IgA}$ and $\mathrm{IgG}$ against the $\mathrm{SE}$ antigens, were higher in the $\mathrm{A} / \mathrm{J}$ (resistant) infected mice; practically during the whole period of infection. These data indicate an importance of $\operatorname{IgM}, \operatorname{IgA}$ and $\operatorname{IgG}$ isotypes of immunoglobulins in the evolution of experimental lagochilascariosis in mice.

Anti-helminth immunity involves $\mathrm{CD}^{+} \mathrm{T}$ cells, yet the precise effector mechanisms responsible for parasite killing or expulsion remain elusive; however, B-cells play a fundamental role in host defense. Antibody-mediated immunity appeared to involve multiple mechanisms including Fc $\gamma-\mathrm{R}$ and complement activation. Antibodies also act as sentinels, by surveying the body for the presence of nonself antigens; as inducers of the immune response, by presenting antigens to specific T-cells; and as effector cells, by differentiating the producers of specific antibodies in plasma cells (Acosta-Rodriguez et al., 2007).

Elevated levels of antigen-specific IgG1, IgG2a, IgG2b and IgA were observed during experimental infection by Brugia malayi, and correlates with resistance to infection (Shakya et al., 2009). Nisbet et al. (2010) denoted that secretory/excretory antigens of Teladorsagia circumcincta are targets of early IgA response in infected sheep. In mice infected by Vampirolepis nana, expulsion of the parasite is closely associated with the appearance of parasite-specific IgA (Matsuzawa et al., 2008). McCoy et al. (2008) reported an essential role for antibodies in mediating immunity against Heligmosomoides polygyrus, a natural murine parasite that establishes chronic infection. Polyclonal or low affinity IgG1 and IgE produced following $H$. polygyrus infection limited egg production by adult parasites. However parasite specific IgG and IgA antibodies were required to prevent adult worm development, but IgE was not found to play an important role in protective immunity against $H$. polygyrus. It is important to remember that eosinophils present the receptor for $\operatorname{IgA}$, indicating a participation of this isotype of immunoglobulin in allergy and helminth infections (Pleass et al., 2007).

Specific IgG and IgA antibodies appeared to be involved in the improved course of murine lagochilascariosis in $\mathrm{A} / \mathrm{J}$ infected mice, and we will investigate in the future, the participation of the sub-classes of $\operatorname{IgG}$ and $\operatorname{IgA}$, separately in the evolution of infection and immunity to the parasite.

\section{Acknowledgements}

This work was financed by FAPEG (grant 02/2007).

\section{References}

Acosta-Rodriguez, E. V., Merini, M. C., Montes, C. L., Motrán, C. C., GRUPPI, A. (2007): Cytokines and chemokines shaping the B-cell compartment. Cytokine Growth Factor Rev., 18: 73 - 83. DOI: 10.1016/j.cytogfr.2007.01.007 Fraiha Neto, H, Leão, R. N. Q., Costa, F. S. A. (1989): Lagochilascariase humana e dos animais domésticos. Zoon. Rev. Int., 1: $25-33$

Freitas, J. A. G., Prudente, M. F., Carvalhaes, M. S. (2009): Experimental lagochilascariosis in X-chromosomelinked immunodeficient mice. Rev. Soc. Bras. Med. Trop., 42: 381 - 385. DOI: 10.1590/S0037-86822009000400005

Kroese, F. G. M., Cebra, J. J., Van Der Cammen, M. J. F., Kantor, A. B., Bos, N. A. (1995): Contribution of B1 cells to intestinal IgA production in the mouse. Methods (Comp. Met. Enz.), 8: $37-43$

LEIPER, R. T. (1909): A new nematoda worm from Trinidad: Lagochilascaris minor. Proc. Zool. Soc. London, 4: 742 - 743 Matsuzawa, K., Abe, M., Shirakura, T., ZhaO, W. H., NAKAMURA, F. (2008): Spontaneous worm expulsion and intestinal IGA response in mice infected by Vampirolepis nana. Parasitol. Int., 57: 512 - 514. DOI: 10.1016/j.parint. 2008.06.001

McCoy, K. T., Stoel, M., Stettler, R., Merky, P., FinK, K., Senn, B. M., Schaer, C., Massacand, J., Odermatt, B., Oettgen, H. C., Zinkernagel, R. M., Bos, N. A., Hengartner, H., Macpherson, A. J., Harris, N. L. (2008): Polyclonal and specific antibodies mediate protective immunity against enteric helminth infection. Cell Host Microbe, 4: 362 - 373. DOI: 10.1016/j.chom.2008.08.014 Nisbet, A. J., Smith, S. K., Armstrong, S., Meikle, L. I., Wildblood, L. A., Beynon, R. J., Matthews, J. B. (2010): Teladorsagia circumcincta: Activation-associated secreted proteins in excretory/secretory products of fourth stage larvae are targets of early IgA responses in infected sheep. Exp. Parasitol., 125: 329 - 337. DOI: 10.1016/j.exp para.2010.02.014

Oliveira, J. A., Barbosa, C. A., Vieira, M. A., Fiorini, M. O., CAMPOS, D. M. B. (2002): Isolado de Lagochilascaris minor: procedimentos para obtenção de ovos infectantes. Rev. Patol. Trop., 31: $121-128$ 
Pleass, R. J., Lang, M. L., Kerr, M. A., Woof, J. M. (2007): $\operatorname{IgA}$ is a more potent inducer of NADPH oxidase activation and degranulation in blood eosinophils than IgE. Mol. Immunol. 44: 1401 - 1408. DOI: 10.1016/j.molimm. 2006.05.002

Prudente, M. F., Freitas, J. G., Ribeiro, E. L., CarvalHAES, M. S. (2009a): Influence of the genetic pattern and sex of mice in experimental lagochilascariosis. Helminthologia, 46: 31-34. DOI: 10.2478/s11687-009-0006-y

Prudente, M. F., Crespo, A. M. C., Carvalhaes, M. S. (2009b): Lagochilascaris minor: antibody production in experimentally infected mice. Rev. Soc. Bras. Med. Trop. 42: 325 - 328. DOI: 10.1590/S0037-86822009000300016 Prudente, M. F., Lino, R. S., Carvalhaes, M. S. (2009c): The X-chromossome-lynked immunodeficiency determines na improved course of murine lagochilascariosis. Helminthologia , 46: 205 - 208. DOI: 10.2478/s11687009-0038-3

Sakamoto, T., Cabrera, P. A. (2002): Subcutaneous infection of Lagochilascaris minor in domestic cats from Uruguay. Vet. Parasitol., 108: 145 - 152. DOI: 10.1016/S0 304-4017(02)00178-4

SEMERENE, A. R., LINO-JUNIOR, R. S., ARAÚJO DE
Oliveira, J., Magalhães, A. V., Stefani, M. M. A., BarBosa, A. P., CAMPos, D. M. B. (2004): Experimental lagochilascariosis: histopathological study of inflammatory response to larval migration in the murine model. Mem. Inst. Oswaldo Cruz, 99: 393 - 398. DOI: 10.1590/S007402762004000400009

ShaKya, S., Singh, P. K., KushwahA, S., MisRA-BhAtTACHARYA, S. (2009): Adult Brugia malayi $\sim 34 \mathrm{kDa}$ (BMT-5) antigen offers TH1 mediated significant protection against infective larval challenge in Mastomys coucha. Parasitol. Int., 58: 346 - 353. DOI: 10.1016/j.parint.2009.07.007 Spadafora-Ferreira, M., Fernandes, L. C., Pfrimer, I. A. H., Pichiteli, C. R., TAmbourgi, D. V., Lino-Junior, R. S., CARVAlhaes, M. S. (2010): Lagochilascaris minor: Susceptibility and resistance to experimental infection in mice is independent of $\mathrm{H}-2^{\mathrm{a}}$ haplotype and correlates with the immune response in immunized animals. J. Parasitol. Res., 1: 1 - 8. DOI: 10.1155/2010/610457

Volcan, G. S., Medrano, C. E., Payares, G. (1992): Experimental heteroxenous cycle of Lagochilascaris minor Leiper, 1909 (Nematoda: Ascarididae), in white mice and cats. Mem. Inst. Oswaldo Cruz, 87: 535 - 532. DOI: 10.1590/S0074-02761992000400010 